\title{
FATHOM
}

\section{Reality in Excess}

Letters and Telegrams in Thomas Hardy's Poetry

Lettres et télégrammes: les "excès de réel" dans la poésie de Thomas Hardy

\section{Laurence Estanove}

\section{(2) OpenEdition}

Journals

Electronic version

URL: http://journals.openedition.org/fathom/761

DOI: 10.4000/fathom.761

ISSN: 2270-6798

Publisher

Association française sur les études sur Thomas Hardy

\section{Electronic reference}

Laurence Estanove, «Reality in Excess », FATHOM [Online], 1 | 2013, Online since 17 May 2013, connection on 24 April 2019. URL : http://journals.openedition.org/fathom/761 ; DOI : 10.4000/ fathom.761

This text was automatically generated on 24 April 2019. 


\title{
Reality in Excess
}

\author{
Letters and Telegrams in Thomas Hardy's Poetry \\ Lettres et télégrammes: les "excès de réel" dans la poésie de Thomas Hardy
}

\section{Laurence Estanove}

1 Sticking to "the letter of the letter" in Hardy's work is in reality much more productive than one might first consider. Our primary concern here is the letter as means of communication in Hardy's poetry, yet, as we shall see, the importance of the letter of the alphabet as graphic insertion is also particularly relevant to the writer's mode of exploration of literality. A close scrutiny of the presence of letters or telegrams in Hardy's verse indeed casts light on a perfect equation of letter and poem, as letters and poems often bear the very same functions in his poetical work.

In Hardy's poetry, letters, notes and telegrams are often linked to the experience of disappointed love, and often read under the ambivalent light of either sun or moon. This is obviously the case of two poems which immediately call for a parallel reading and analysis, despite their having been published at various dates - "The Sun on the Letter" ( Time's Laughingstocks, 1909; Hardy 2001, 231) and "Read by Moonlight" (Late Lyrics and Earlier, 1922; Hardy 2001, 5741).

The Sun on the Letter I drew the letter out, while gleamed The sloping sun from under a roof And cloud whose verge rose visibly. The burning ball flung rays that seemed Stretched like a warp without a woof Across the levels of the lea To where I stood, and where they beamed As brightly on the page of proof That she had shown her false to me As if it had shown her true - had teemed With passionate thought for my behoof Expressed with their own ardency! 


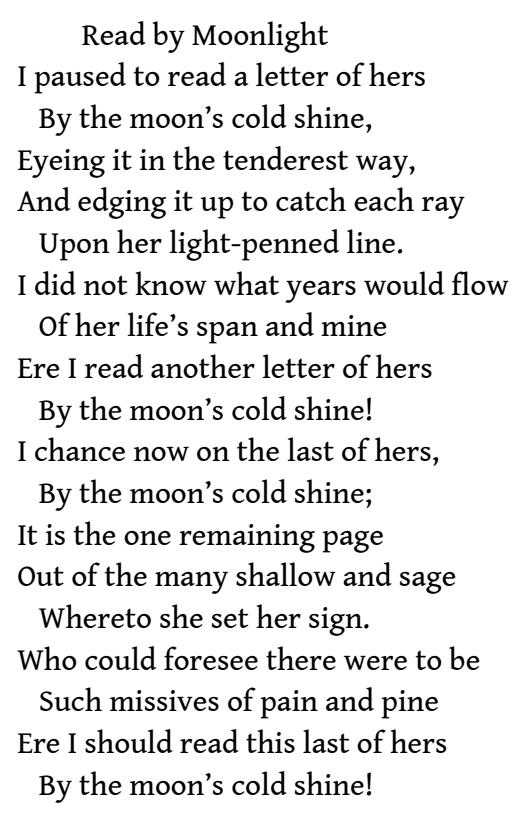

3 In both cases, the process of reading the letter is not an easy one, either sustained by a light that is only indirect, as if sly or uncertain ("sloping sun", "stretched like a warp without a woof"), or necessitating the right re-adjustment ("edging it up to catch each ray"). The oxymoron acting as refrain for "Read by Moonlight" - "the moon's cold shine" - thus summarizes how the whole poem functions, relying on obvious contrasts ("the one remaining page / Out of the many") as well as unexpected associations ("shallow and sage"). The effect is also visual and geometrical, since the edging rays of the moonlight come to cross the woman's "light-penned line". In both poems, deceit is in the light, and in both, whether bright and burning or cold, the light has the same effect: setting out an ironic disclosure of the truth. In "The Sun on the Letter", that disclosure actually follows the opening of the letter ("I drew the letter out"), yet ironically, this double unfolding, of letter and truth ("the page of proof"), in fact reveals that the woman has been untrue. The typically Hardyan device of lexical conversion or zero derivation - here in the nominalization of adjectives "true" and "false" - plainly reinforces the ambiguity of the woman's behaviour, just as the parallel syntax of both lines ("she had shown her false to me / As if it had shown her true") comes to enhance the elementary contrast. Similarly in "Read by Moonlight", the two stanzas are sustained by a parallel syntax, but also opposed by a radical change in the perception of the letter, from "the tenderest way" to "pain and pine".

4 In the two poems, the letter thus signals both a continuity and a rift. In "Read by Moonlight", the continuity is a temporal one, the "flow" and "span" of years leading from the reading of one letter to the next, but also a syntactic one between the opening of each stanza, since the anaphoric "the last of hers" paradoxically gives the implicit word "letter" an all too powerful presence. Besides, the whole letter appears to its reader as one single continuous line, as the use of the singular in the alliterative "light-penned line" shows. This leads one to read the poem itself as a single continuous line connecting the past and present unique readings of "I paused" and "I chance". Yet there is obvious irony in the temporal connection embodied by the letter, which actually exposes one of "time's laughingstocks". Indeed, as "The Sun on the Letter" most clearly shows, the letter as "page of proof" signals a rift, an almost tangible, physical mark or imprint, bearing witness to the breach in trust. That broken continuity appears in the vision of the 
sunlight as an unfinished weaving ("like a warp without a woof"), as well as in the conflicting lines and declivities of the landscape ("Across the levels of the lea"). It is the tension within the layout of the poem itself which is thus put forward, the play between the horizontality of lines and verticality of stanzaic organisation. Therefore that continuity operates at a thematic but also structural level, a continuity between subject and text indeed enhanced by the pattern and syntax of the poems. In "The Sun on the Letter", from stanza 2 to 4 , the poem unfolds in a single sentence with hardly any pause, hardly any punctuation, precisely as if following the actual unfolding of the letter and revelation of the truth at the same time.

Hence the illuminated letter becomes in turn enlightening, and the actual irony of correspondence between light, letter and truth that these poems set out is visible in several other Hardy poems, such as "A Wife in London" (Hardy 2001, 91-92²). Here, the irony is all the more powerful and scathing because it relies on the mistiming of both telegram and letter:

A Wife in London

$$
\text { I }
$$

She sits in the tawny vapour That the Thames-side lanes have uprolled, Behind whose webby fold on fold

Like a waning taper

The street-lamp glimmers cold.

A messenger's knock cracks smartly, Flashed news is in her hand of meaning it dazes to understand

Though shaped so shortly: $\mathrm{He}$ - has fallen - in the far South Land... . II

'Tis the morrow; the fog hangs thicker, The postman nears and goes:

A letter is brought whose lines disclose

By the firelight flicker

His hand, whom the worm now knows:

Fresh - firm - penned in highest feather Page-full of his hoped return,

And of home-planned jaunts by brake and burn

In the summer weather,

And of new love that they would learn.

6 The parallel organization of the two parts is obvious: "tawny vapour" is echoed by "the fog hangs thicker", the "street-lamp glimmer" by the fireplace flicker, and the sudden coming of the telegram which "[f]lashed" the deathly news by the ordinarily brief appearance of the postman ("The postman nears and goes"). In both cases also, reading is for the young widow a painstaking enterprise which can be perceived - seen and heard - in the recurring dashes sustaining the description of each text: "He - has fallen - in the far South Land....", "Fresh - firm - penned in highest feather -". The cruel irony of the situation is therefore imparted to the very shape of the poem, since the woman's loss is embedded and twice inscribed within the text - through telegram and through letter. Similarly, in "Read by the Moonlight", the illuminated letter acts both as a circumstantial and poetic leitmotif: between the past in the first stanza, and the disillusioned present of the second, the refrain "I paused to read a letter of hers / By the moon's cold shine" adds a sense of linguistic continuity to the echo of the memory. 
7 In some other poems, sun or moonlight are again associated with love letters: in "The Torn Letter" (Hardy 2001, 313-3143) it is the moon ("the midnight whitened") which sustains the bitter remorse of the speaker trying to patch up / piece together the love letter he tore up in a fit of passion, while in "The Love-Letters" (Hardy 2001, 8414) the sunset maps out the decline and coming death (possibly suicide) of the rejected lover who has just been given back his old letters:

The Love-Letters

(In Memoriam H. R.)

I met him quite by accident

In a by-path that he'd frequent.

And, as he neared, the sunset glow

Warmed up the smile of pleasantry

Upon his too thin face, while he

Held a square packet up to me, of what, I did not know.

"Well," said he then; "they are my old letters.

Perhaps she - rather felt them fetters....

You see, I am in a slow decline,

And she's broken off with me. Quite right

To send them back, and true foresight;

I'd got too fond of her! To-night

I burn them - stuff of mine!"

He laughed in the sun - an ache in his laughter -

And went. I heard of his death soon after.

The near chiasmus at the end, "He laughed in the sun - an ache in his laughter -", again sustained by the presence of dashes, materializes the irony of the text, since it assimilates very simply sun and suffering. In "The Telegram" (Hardy 2001, 391-3925), the letter (or telegram) and the moon are again present, apparently only as details, but in reality their association builds the very continuity and unity of the text, a thematically and subjectively complex piece. Two newly-wed couples unknown to one another are at a spa town; the speaker is the bridegroom of one of the couples, while the bride of the other couple receives a telegram, the appearance of which will then reveal the two couples' similar fates.

The Telegram

"O he's suffering - maybe dying - and I not there to aid, And smooth his bed and whisper to him! Can I nohow go?

Only the nurse's brief twelve words hurriedly conveyed, As by stealth to let me know.

"He was the best and brightest! - candour shone upon his brow, And I shall never meet again a soldier such as he,

And I loved him ere I knew it, and perhaps he's sinking now, Far, far removed from me!"

- The yachts ride mute at anchor and the fulling moon is fair, And the giddy folk are strutting up and down the smooth parade, And in her wild distraction she seems not to be aware That she lives no more a maid,

But has vowed and wived herself to one who blessed the ground she trod To and from his scene of ministry, and thought her history known

In its last particular to him - aye, almost as to God, And believed her quite his own.

So rapt her mind's far-off regard she droops in a swoon,

And a movement of aversion mars her recent spousal grace, 
And in silence we two sit here in our waning honeymoon

At this idle watering-place....

What now I see before me is a long lane overhung

With lovelessness, and stretching from the present to the grave.

And I would I were away from this, with friends I knew when young,

Ere a woman held me slave.

The sudden appearance of the telegram and its discovery by the bride sets off the poem, once again signalling a rift, since this initial trigger reveals the breach in trust between husband and wife. It is then the moon, "fair" and "fulling", which connects with strong irony these two to the second couple. The speaker indeed presents it as a mockery of his own tainted marriage, his own "waning honeymoon". Through the lexical pun, the poem thus creates the opportunity of an unexpected correspondence between the two couples, and between past and present for the speaker revealing in the last stanza his own bitter disillusionment in matrimony ${ }^{6}$.

Letters in Hardy's poetry are therefore means for both union and division - division since they reveal unfaithfulness or deceit of some sort, and union because they weave a web-like continuity between people, places, and events. Hardy's conviction that poetry is the most efficient conveyor of truth ${ }^{7}$ is also made obvious in the way the letter motif participates in poetic continuity, what Henri Meschonnic saw as poetic rhythm - the continuity between text and world ${ }^{8}$. Here the conjunction between light, letter, and poem clearly sets out a genuine dramatization of the truth, a complex form of visual redundancy - a genuine irony of correspondence.

This is how Hardy's poetry can be taken to materialize what Jean Baudrillard calls "the irony of too much reality". In the poems just studied, this excess in reality appears in the way the light seems to re-enact, to reinforce the bare cruel truth that the letter or telegram brings forth. This form of visual redundancy is also dramatized in some of Hardy's illustrations for his first collection of verse, Wessex Poems, published in 1898. The case of "In a Eweleaze Near Weatherbury" (Hardy 2001, 70-71) catches attention most strikingly.

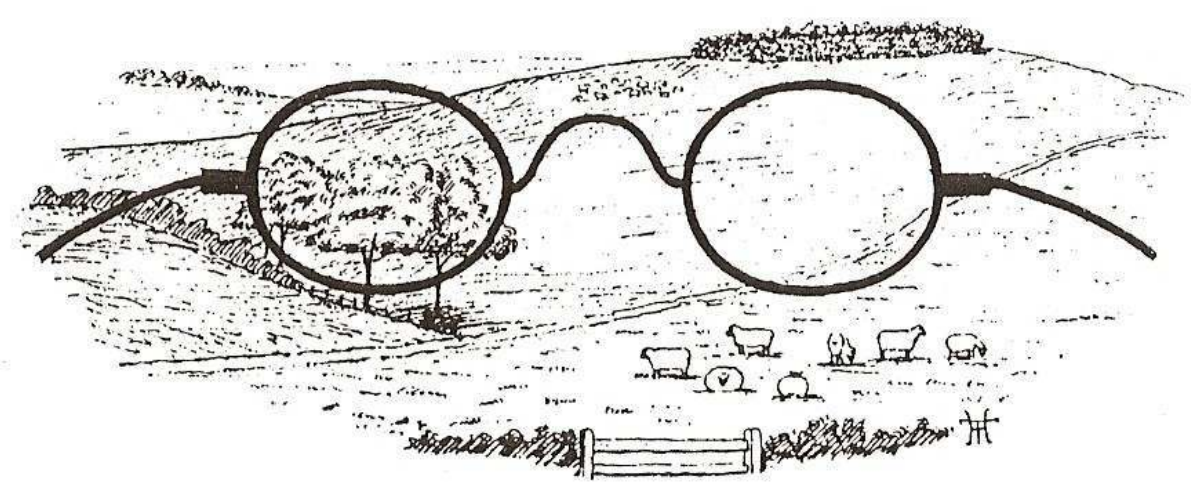

"Illustrations to Wessex Poems" 154

Paul Zietlow noted: "Enigmatically, the spectacles produce no distortion or magnification in that part of the scene which is viewed through them" (Zietlow 4). In the poem, the female speaker has to face the excessive reality of ephemeral beauty: to her, nothing has changed, but her own perspective can in no way alter the reality of her lost youth, like a landscape that no pair of spectacles can modify. Surprisingly, this duplication of reality creates the uneasiness of an unrealistic perception, an impression which is actually 
perfectly consistent with Hardy's work as a whole, since he was anything but a realistic writer.

This irony of too much reality is another illustration of how, in Hardy's work, "the letter killeth", as runs the famous epigraph from Jude the Obscure. Semantic and semiotic excess is at the core of the relation between letter and poem, as both point to the power of the written word in its dramatized form - in the sense of exposure, of exhibition of the truth via a careful laying out of the text, a concern for its visual as well as semantic effects. Letter and poem are in this respect plainly similar, and this is also precisely what an epigraph does: to put the text forward, to expose it before anything else is read. Like "the letter killeth", other Hardyan epigraphs bear this obvious function of exposure of the truth, foreshadowing the tragedies to come. Tess's fate is indeed, like Jude's, determined by the powerful nature of words, and by the violence imposed on her by the adoption of a noble name - D'Urberville instead of Durbeyfield, the "wounded name" of the Shakespearean epigraph ${ }^{10}$. Within the novels, the most powerful texts are again those which are clearly laid out for everyone to see: Jude's carving of his initials on a milestone ("THITHER / J. F." [Hardy 1998a, 73]), his and Sue's relettering of the Ten Commandments and the churchwarden's anecdote of the disappearing "Nots" (Hardy 2003b, 300-304); in Tess, of course, the capital letters of the "staring vermilion words"11 from the Scriptures painted on gates or stiles, or the gothic lettering of the latin inscription on the Kingsbere Church family vault (Hardy 2003b, 363); and in Far From the Madding Crowd, Bathsheba's valentine to Boldwood imprinted like a blot on his retina ${ }^{12}$. All these are always clearly set out from the body of the text and made thus more visible on the page. Another example of the visual power of words and of its combination with truth is, in The Woodlanders, Marty South's two-line poem scraped in charcoal on the wall of Giles's house: "Oh Giles you've lost your dwelling-place, / And therefore Giles you'll lose your Grace!" - lines indeed raising in Giles "a terrible belief that they were turning out to be true" (Hardy 1998b, 107).

However, if words, lines, letters and telegrams can be seen as weapons of truth, they can also prove harmful for their very authors. Indeed, ultimately the poet's own voice has to suffer an ironical duplication of the text, since the letter itself becomes the incongruous persona of one of Hardy's poems, "The Letter's Triumph" (Hardy 2001, 898-899 ${ }^{13}$ ). The power of the letter over its own sender is thus the very subject of the poem:

The Letter's Triumph (A Fancy)

Yes: I perceive it's to your Love

You are bent on sending me. That this is so

Your words and phrases prove!

And now I am folded, and start to go,

Where you, my writer, have no leave to come:

My entry none will know!

And I shall catch her eye, and dumb

She'll keep, should my unnoised arrival be Hoped for, or troublesome.

My face she'll notice readily:

And whether she care to meet you, or care not, She will perforce meet me;

Take me to closet or garden-plot

And, blushing or pouting, bend her eyes quite near, Moved much, or never a jot. 
And while you wait in hope and fear,

Far from her cheeks and lips, snug I shall stay

In close communion there,

And hear her heart-beats, things she may say,

As near her naked fingers, sleeve, or glove

I lie - ha-ha! - all day.

Like an epigraph before a novel, the letter comes first, preceding and even usurping the place of the person writing it. The irony is here of a less bitter or scathing sort, as the poem is indeed "a fancy", lighter than the ones quoted before. But it clearly reveals that the letter acts both on recipient and sender. The systematic use of "or" points to the sender's own powerlessness, and the mocking tone of the letter - neither of its text nor of its contents, but of itself as speaking subject - points to the poet's awareness of the independence of his text once written, something Hardy had always been sensitive to, especially as regards the reception of his works. "How strange", he wrote in April 1892, "that one may write a book without knowing what one puts into it - or rather, the reader reads into it! Well, if this sort of thing continues no more novel-writing for me. A man must be a fool to deliberately stand up to be shot at" (Hardy 1989, 259). The poem "To a Lady" (Hardy 2001, 65 ${ }^{14}$ ), most probably written around that same period, echoes the same feelings:

\section{To a Lady}

Offended by a Book of the Writer's

Now that my page is exiled, - doomed, maybe,

Never to press thy cosy cushions more,

Or wake thy ready Yeas as heretofore,

Or stir thy gentle vows of faith in me:

Knowing thy natural receptivity,

I figure that, as flambeaux banish eve,

My sombre image, warped by insidious heave

Of those less forthright, must lose place in thee.

So be it. I have borne such. Let thy dreams

of me and mine diminish day by day,

And yield their space to shine of smugger things;

Till I shape to thee but in fitful gleams,

And then in far and feeble visitings,

And then surcease. Truth will be truth alway.

For the writer, the exile or doom of the text is thus both its dismissal by a disapproving reader, and its newly-acquired independence from its creator. The book of the poem's subtitle is only a "page", a synecdoche which actually gives strength to the novel in question (most probably Tess or Jude), thus presented as a coherent piece, its reading as a powerfully immediate experience, like the reading of a letter. And, like the letters of Hardy's fictional pieces, the novel of this personal poem is what comes to break the continuity between writer and reader: the writer's image is "warped", his shape broken up - again - by a jerky feeble light ("fitful gleams"). After such a distortion, in the sonnet's sestet, the gradual disappearance of the poet's image thus shatters the assertive strength of the final maxim. The poet's confidence in his own writing might be but an act, and his belief that "[p]erhaps [he] can express more fully in verse ideas and emotions which run counter to the crystallized opinion" (Hardy 1989, 302 ${ }^{15}$ ) but part of some typically Hardyan instinct for self-protection. 


\section{BIBLIOGRAPHY}

Baudrillard, Jean, De la Séduction, Paris: Galilée, 1979.

Dessons, Gérard \& Henri Meschonnic, Traité du rythme (des vers et des proses), Paris: Dunod, 1998.

Hardy, Thomas, The Life and Work of Thomas Hardy, ed. Michael Millgate, London: Macmillan, 1989.

Hardy, Thomas, Jude the Obscure (1895), ed. Dennis Taylor, London: Penguin Classics, 1998.

Hardy, Thomas, The Woodlanders (1887), ed. Patricia Ingham, London: Penguin Classics, 1998.

Hardy, Thomas, The Complete Poems, ed. James Gibson, Basingstoke: Palgrave, 2001.

Hardy, Thomas, Far from the Madding Crowd (1874), ed. Rosemarie Morgan, London: Penguin Classics, 2003.

Hardy, Thomas, Tess of the d'Urbervilles, (1891) ed. Tim Dolin, London: Penguin Classics, 2003.

"Illustrations for Wessex Poems", Victorian Poetry 17 (1979): 135-154.

Taylor, Dennis, “Chronology of Hardy’s Poetry”, Victorian Poetry 37.1 (Spring 1999): 1-58.

Zietlow, Paul, Moments of Vision: The Poetry of Thomas Hardy, Cambridge, MA: Harvard UP, 1974.

\section{NOTES}

1. In his "Chronology of Hardy's Poetry", Dennis Taylor provides no date for the writing of these two pieces.

2. Poems of the Past and the Present, 1901 (written in 1899).

3. Satires of Circumstance, 1914 (first published in 1910).

4. Winter Words, 1928.

5. Satires of Circumstance, 1914 (first published in 1913).

6. While sunshine often comes as a revelator of the vanity of existence ("A Drizzling Easter Morning", Hardy 2001, 658-659), moonshine in Hardy's poetry is more specifically connected to the exhibition of the irony of love, as one may also read in "In the Moonlight" (Hardy 2001, 423) or "The Moon Looks In" (Hardy 2001, 390-391).

7. See his famous note from October 1896: "Poetry. Perhaps I can express more fully in verse ideas and emotions which run counter to the crystallized opinion - hard as a rock - which the vast body of men have vested interest in supporting. To cry out in a passionate poem that (for instance) the Supreme Mover or Movers, the Prime Force or Forces, must be either limited in power, unknowing, or cruel - which is obvious enough, and has been for centuries - will cause them merely a shake of the head; but to put it in argumentative prose will make them sneer, or foam, and set all the literary contortionists jumping upon me, a harmless agnostic, as if I were a clamorous atheist, which in their crass illiteracy they seem to think is the same thing.... If Galileo had said in verse that the world moved, the Inquisition might have let him alone." (Hardy 1989, 302)

8. Here is Meschonnic's definition of poetic rhythm: “tout ce qu'il y a aussi dans le langage et qui est de l'ordre du continu, entre le corps et le langage, entre une langue et une littérature, entre 
une langue et une pensée : un ensemble de dispositifs signifiants qui sont des sémantiques du continu." (Dessons \& Meschonnic 38)

9. "l'ironie du trop de réalité" (Baudrillard 91).

10. “... Poor wounded name! My bosom as a bed / Shall lodge thee.” (Hardy 2003b, 1)

11. Hardy 2003b, 79-80.

12. "Here his gaze was continually fastening itself, till the large red seal became as a blot on the retina of his eye; and as he ate and drank he still read in fancy the words thereon, although they were too remote for his sight.

MARRY ME"

(Hardy 2003a, 87)

13. Winter Words, 1928 (written between 1924 and 1928).

14. Wessex Poems, 1898.

15. See above, note 7 .

\section{ABSTRACTS}

In Hardy's poetry, letters, notes and telegrams are most commonly linked to the experience of disappointed love. Those letters often reveal themselves under the ambivalent light of either sun or moon, and therefore convey the most painful truth in a highly ironical manner. As the means for both union and division, letters are weapons because they control their senders and recipients by weaving a web-like continuity between people, places and events. Hardy's conviction that poetry is the most efficient conveyor of truth is also made clear in the way the letter motif participates in poetic continuity: the conjunction of lit letter and poem enables a genuine dramatization of the truth, as the vertical unfolding of the poem reproduces that of the letter. Through this unique and complex form of visual tautology - this actual irony of correspondence -, Hardy's poetry materializes what Jean Baudrillard calls "the irony of too much reality", indeed asserting once more the author's belief that "the letter killeth". Ultimately, the poet's own voice has to suffer this ironical redoubling of the text, which consequently also concerns the relation between writer, text, and reader.

Dans la poésie de Hardy, les lettres, notes et télégrammes apparaissent le plus souvent dans le contexte de la déception amoureuse. Ces lettres se dévoilent aussi souvent sous la lumière ambivalente du soleil ou de la lune, transmettant ainsi de douloureuses vérités de manière hautement ironique. Vecteurs d'union et de désunion, les lettres sont des armes car elles agissent sur leurs expéditeurs et destinataires en tissant la toile d'une continuité entre les êtres, les lieux et les événements. Hardy voyait dans la poésie le relais le plus efficace de la vérité, ce qui apparaît dans la façon dont la lettre participe également à une continuité poétique : le poème se déroule verticalement comme se déplie la lettre, et cette adéquation permet ainsi une authentique mise en scène, ou mise en espace, de la vérité. Par le biais de cette forme complexe de tautologie visuelle - véritable ironie de la correspondance - la poésie de Hardy incarne ce que Jean Baudrillard nomme "l'ironie du trop de réalité ", affirmant ainsi une fois de plus la conviction qui sert d'épigraphe à Jude the Obscure - «the letter killeth ». C'est, en dernier lieu, la voix de l'auteur lui-même qui va subir les conséquences de ce redoublement ironique du texte, ironie qui va donc toucher également la relation entre écrivain, texte, et lecteur. 
INDEX

oeuvrecitee Sun on the Letter (The), Read by Moonlight, Wife in London (A), Love-Letters (The), Telegram (The), Letter's Triumph (The), To a Lady, Poems of the Past and the Present, Satires of Circumstance, Winter Words, Wessex Poems

Keywords: letter, telegram, poetry, love, disillusionment, irony, reality, poetics

Mots-clés: lettre, télégramme, poésie, amour, désillusion, ironie, réel, poétique

\section{AUTHOR}

\section{LAURENCE ESTANOVE}

Université Paris-Descartes / Université de Toulouse - CAS

Professeur agrégée

Docteur 